\title{
Novel Composite Films Based on Acrylic Fibers Waste/Nano-chitosan for Congo Red Adsorption
}

\author{
Salah E. Selim ${ }^{1} \mathbb{D} \cdot$ Gamal A. Meligi ${ }^{2} \cdot$ Ahmed E. Abdelhamid $^{3} \cdot$ Mahmoud A. Mabrouk $^{1} \cdot$ Ahmed I. Hussain $^{3}$
}

Accepted: 6 January 2022 / Published online: 24 January 2022

(c) The Author(s) 2022

\begin{abstract}
The current research aimed to use waste to treat waste; to recycling of acrylic fibers waste combined with nano-chitosan for use as an adsorbent to remove Congo red (CR) from wastewater. Acrylic fibers (AF) waste were mixed with nano-chitosan (NCh) with different ratios and converted into films by using phase inversion method to prepare two nanocomposites films coded, AF-NCh and AF-NCh-Epichlorohydrin. The nanocomposites films have been characterized using; Fourier transform infrared, scanning electron microscope, surface area, and thermal analysis. The results revealed successful incorporation of NCh into AF matrix with highly porous structure. Different parameters affecting adsorption efficiency such as, CR concentrations, adsorbent dose, effect of time and $\mathrm{pH}$ were employed. Adsorption isotherms and kinetic studies evaluations were applied to assess the adsorption mechanism and rate. Results declared that, the maximum adsorption capacities of AF-NCh and AF-NCh-Epichlorohydrin were 169 and $230 \mathrm{mg} / \mathrm{g}$ respectively. The adsorption isotherm and kinetic mechanism obey Langmuir and pseudo second order models. Regeneration of the synthesized composite films were studied for five cycles and showed relative stable reading with high efficiency.
\end{abstract}

\section{Graphical Abstract}

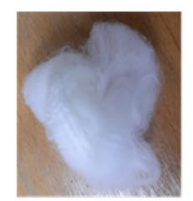

Acrylic Fibers

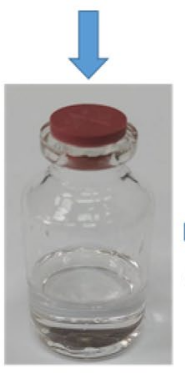

DMF Solvent
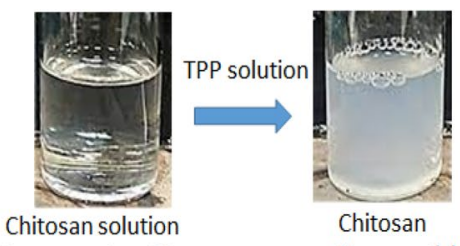

in $1 \%$ acetic acid
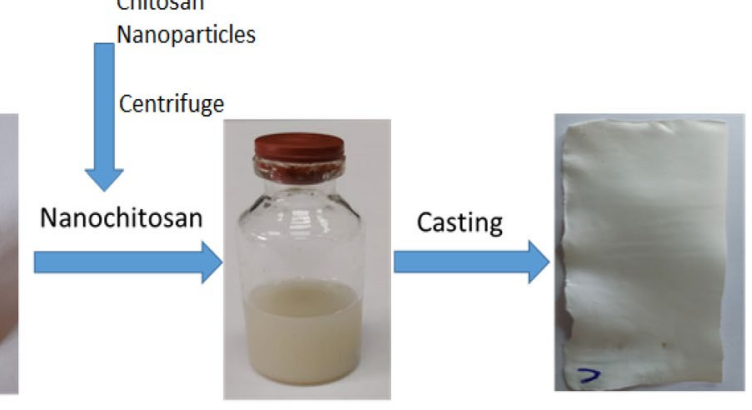

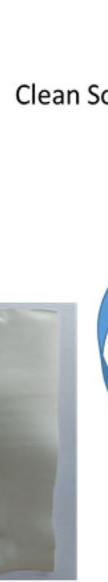

Clean Solution

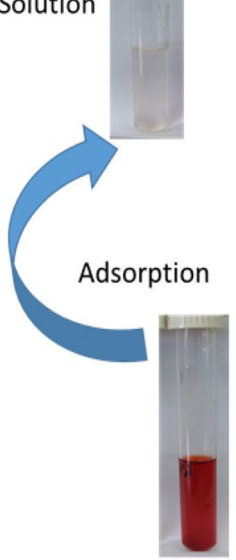

Contaminated Solution

Keywords Acrylic fiber - Nanochitosan · Composite film · Water treatment $\cdot$ Congo red

Salah E. Selim

salah@eaeat.edu.eg

Extended author information available on the last page of the article 


\section{Introduction}

Synthetic dyes are used in a variety of industries, including leather, paper, and textiles, because of their colorgiving properties. Each year, it is estimated that 700,000 tons of various colorants are produced from approximately 100,000 commercially available dyes [1-3]. Azo dyes are complex aromatic compounds and they are a major environmental concern because the reductive cleavage of azo linkages results in the formation of amines, which are toxic and carcinogenic [4]. Congo red (CR) dye is a benzidinebased anionic diazo dye (1-naphthalenesulfonic acid, 3,3'-(4,4'-biphenylenebis(azo))-bis(4-amino) disodium salt), and it was reported as carcinogen and affect the aquatic life $[5,6]$. Numerous studies are currently being conducted to determine the best dye removal process, so that dye wastewater can be recovered and reused [7-9].

Existing dye removal methods can be classified into biological, chemical, and physical processes such as; coagulation, flocculation, chemical oxidation, photochemical degradation, membrane filtration, biological degradation and adsorption are mostly techniques used for removing dyes from an aqueous medium [10]. However all of the methods mentioned above, have some disadvantages, and none of them have been effective in completely removing dye from wastewater [11]. The most economic and environmental effective method is the physical one as it didn't involve using of toxic chemicals and didn't leave toxic byproducts. Physical techniques used in the dye removal process can be divided into membrane based technique and adsorption. Adsorption process is considered one of the most favorable technique because its remarkable ability to remove most types of dyestuff in addition to its simplicity and efficiency and reusability [12-16]. Numerous types of adsorbents have been employed for water treatment. Activated carbon is one of the most widely used adsorbent for dye removal [17-21]. Biopolymers as chitosane and nanochitosane and their composites were used as a prominent adsorbent for heavy metals and CR removal [22-30]. Different nanomaterials and nanocomposites have been used in a variety of science applications such as biomedical and environmental, especially as dye's adsorbants [31-40].

Another class of materials are the fuzzes and fibers waste that produce from textile industry can cause environmental problem issues. As a result, researchers have attempted to use fibres waste in several application as concrete and soil reinforcement, as well as in the adsorption process but after chemical treatment. Acrylic fibers mainly composed of at least $85 \%$ acrylonitrile and the remaining another acrylic monomer. However, there are limited research paper dealing with the recycling of acrylic fibers waste for water remediation application. Lehia and Akbari used acrylic fibers and fuzzes wasted in carpet industries to prepare adsorption membrane for removing Persian Orange $X$ from textile effluents [41]. Poly acrylonitrile Nanofiber materials have been recently used as CR adsorbent and heavy metal removal [42-45]. Also modified acrylic fiber waste have been recently used for removal CR, methylene blue and uranium, thorium from liquid waste solution $[46,47]$.

This research work was aimed to prepare novel nanocomposites films based on commercial acrylic fibers waste as a polymer matrix incorporated with a highly adsorptive nanomaterials; nanochitosane and their study in adsorption of CR from aqueous solution. Different parameters affecting the adsorption efficiency such as CR concentrations, adsorbent dose, effect of time and $\mathrm{pH}$ were investigated. Also kinetic study and isotherm of adsorption process were studied. Also many cycles of film reuse were investigated to assess the adsorption stability.

\section{Experimental}

\section{Materials}

Acrylic fiber waste (AF) consisting of at least $85 \%$ polyacrylonitrile as a major constituent and the residual mainly vinyl acetate or methyl acrylate copolymer. AF waste was obtained from local textile industry. Congo red dye was supplied from Alpha Aeser, India, Commercial Chitosan of low molecular weight $(150 \mathrm{kDa})$, Trisodium polyphosphate (TPP), Epichlorohydrin (EPH) and Dimethylformamide (DMF) were purchased from Sigma Aldrich, USA. Hydrochloric acid and Sodium hydroxide and other solvents were supplied from El-Nasr Company Egypt.

\section{Preparation of Nanochitosan}

Nanochitosan was synthesized according to ionic gelation method using TPP as crosslinking agent [48]. Briefly, one $\mathrm{gm}$ of chitosan was dissolved in $200 \mathrm{ml}$ of $1 \%$ of acetic acid, then 0.66 of TPP was dissolved in $100 \mathrm{ml}$ of distilled water and added drop wise to chitosan solution under constant stirring. The solution was turned onto turbid suspension indicating the formation of nanoparticles. The suspension was left under stirring for another one an hour after complete addition step. The nanochitosan was separated using centrifuge at a maximum of $10.000 \mathrm{rpm}$, and collected then freeze dried.

\section{Preparation of Acrylic Fiber-Nanochitosan Composite Films (AF-NCh)}

Composite films of AF with different ratios of $\mathrm{NCh}(0,10$, $20,30,40,50$ and $60 \mathrm{wt} \%$ ) were prepared as following, a 
predetermined weight of AF waste is dissolved in $10 \mathrm{ml}$ DMF at $70{ }^{\circ} \mathrm{C}$ under stirring for $4 \mathrm{~h}$, then a definite weight of $\mathrm{NCh}$ was added portion wise to the PAN-DMF solution with continuing stirring till obtain a homogenous composite solution. The obtained homogenous suspension was sonicated for $1 \mathrm{~h}$ in ultrasonic water bath to confirm the well distribution of nanochitosan in the polymer matrix. The composite solution was casted in a glass plate using a film applicator. The casting solution was immersed in deionized water for $24 \mathrm{~h}$ to get a film with thickness of $0.12 \mathrm{~mm}$. By adopting the same procedures, other composite film was prepared using a cross linking EPH to assure complete fixation of nanochitosan within the polymer matrix.

\section{Characterization}

\section{FTIR Studies}

To assess the reactive function groups of the composite films FT-IR was used within the range $\left(400-4000 \mathrm{~cm}^{-1}\right)$ using Nicolet Avatar FTIR 370 CSI.

\section{SEM of Composite Film}

Surface morphology and the cross-section topography of the synthesized composite films were investigated using FESEM QUANTA 250. Prior to examination the films were dried and sputtered with gold to minimize charging effect during examination.

\section{TEM of Nanochitosan}

The particle size and shape of synthesized nanochitosan were investigated using HR-TEM, (JEM-2100-TEM). The nanochitosan suspension was sonicated for half an hour and one or two drops were added to the testing grid then left for dyeing.

\section{Brunauer-Emmett-Teller (BET) Measurement}

The Brunauer-Emmett-Teller (BET) measurement was used to assess the surface area of the composite films based on determination of nitrogen adsorption isotherm at $77 \mathrm{~K}$ using the Belsorp adsorption automatic specific surface area analyzer (Microtrac-BEL, Japan).

\section{Thermal Gravimetric Analysis (TGA)}

Thermal stability of the new nanocomposite was investigated using TA Q500 instrument, at a heating rate $10{ }^{\circ} \mathrm{C} /$ min in nitrogen atmosphere.

\section{Adsorption and Optimization Experiments}

Different concentrations of CR dye ranged from 100 to $800 \mathrm{mg} / \mathrm{l}$ have been prepared. The final concentration after adsorption and the feed solution were measured using UV-Vis (Lambda 35 Perkin Elmer) at $\lambda \max =497 \mathrm{~nm}$. A predetermined weight of AF-NCh and AF-NCh-EPH films were inserted into $50 \mathrm{ml}$ glass round flask, then $10 \mathrm{ml}$ of $\mathrm{CR}$ dye solution of variant concentrations were added. The flask was shaken using automatic shaker at $50 \mathrm{rpm}$ for $24 \mathrm{~h}$. Various parameters of adsorption study were employed such as time of shaking, CR dye concentration, adsorbent dose and solution $\mathrm{pH}$.

The adsorption capacity $\mathrm{q}(\mathrm{mg} / \mathrm{g})$ for CR dye can be calculated using the mass balance expression, Eq. (1) [49].

$q_{e}=\left(C_{0}-C_{e}\right) \times \mathrm{V} / \mathrm{m}$,

where $\mathrm{C}_{0}$ and $\mathrm{C}_{\mathrm{e}}$ are the initial and equilibrium concentration of the dye, respectively, expressed in $(\mathrm{mg} / \mathrm{l}), \mathrm{V}$ is the volume of the dye solution in (l) and $\mathrm{m}$ is the mass of the adsorbent in (g).

The removal efficiency at equilibrium can be calculated using the following relation, Eq. (2) [50].

$\% R=\frac{\left(C_{0}-C_{e}\right)}{C_{0}} \times 100$.

\section{Adsorption Isotherm Studies}

Langmuir, Freundlich and Temkin isotherm models were applied to assess the affinity between the adsorbent and adsorbate. The mathematical equations expressed the adsorption models are illustrated below by Eqs. (3), (5) and (6) respectively $[28,51]$.

$\frac{C_{e}}{q_{e}}=\frac{1}{q_{\max } k_{l}}+\frac{C_{e}}{q_{\max }}$,

where $k_{l}$ represents a constant related to the nanocomposites adsorption/desorption capacity, and $\mathrm{q}_{\max }$ is the maximum adsorption capacity upon complete saturation of the nanocomposites, $\mathrm{Ce}(\mathrm{mg} / \mathrm{l})$ is the dye concentration at equilibrium and $\mathrm{q}_{\mathrm{e}}(\mathrm{mg} / \mathrm{g})$ is the adsorption capacity at equilibrium.

The basic parameter of the Langmuir isotherm could be expressed in terms of a unitless equilibrium factor, such as the separation factor or equilibrium factor $\left(R_{\mathrm{L}}\right)$ (Eq. (4)).

$\mathrm{R}_{\mathrm{L}}=1 /\left(1+\mathrm{K}_{1} \mathrm{C}_{0}\right)$,

where, $C_{0}$ is the initial dye's concentration.

The Freundlich isotherm is presented using equation: 
$\log q_{e}=\log K+\frac{1}{n} \log C_{e}$,

where $\mathrm{k}$ and $n$ are empirical constants that can be related to the adsorption capacity and the adsorption affinity, respectively.

The linear form of Temkin equation is expressed by

$q_{e}=B \ln A+B \ln C e$,

where $\mathrm{A}\left(\mathrm{g}^{-1}\right)$ and $\mathrm{B}\left(\mathrm{J} \mathrm{mol}^{-1}\right)$ are the Temkin isotherm parameters relating to the equilibrium binding constant and adsorption heat, respectively.

\section{Kinetic Studies}

Pseudo first order and pseudo second order are most the common kinetic models used for detect the rate of dye adsorption from the aqueous solution. The linear forms of these models can be expressed in the following equations see (7) and (8) [52].

$\log \left(q_{e}-q_{t}\right)=\log q_{e}-k_{1} \times \frac{t}{2.303}$,

where $\mathrm{q}_{\mathrm{e}}(\mathrm{mg} / \mathrm{g})$, is the adsorption capacity at equilibrium, $\mathrm{q}_{\mathrm{t}}(\mathrm{mg} / \mathrm{g})$ is the adsorption capacity at time $\mathrm{t}$, and $\mathrm{k}_{1}$ is the first order rate constant per minute.

A plot of $\ln \left(\mathrm{q}_{\mathrm{e}}-\mathrm{q}_{\mathrm{t}}\right)$ versus time $(\mathrm{t})$ indicates a straight line of slope $\left(-\mathrm{k}_{1} / 2.303\right)$ and an intercept of $\log \left(\mathrm{q}_{\mathrm{e}}\right)$.

Whereas the second order equation can be represented by Eq. (8)

$\frac{t}{q_{t}}=\frac{1}{k_{2} q_{e}^{2}}+\frac{1}{q_{e}} \times t$

where $\mathrm{K}_{2}$ expresses the equilibrium rate constant ( $\mathrm{g} / \mathrm{mg}$ $\min$ ), and $\mathrm{q}_{\mathrm{e}}$ and $\mathrm{q}_{\mathrm{t}}$ express the sorption capacities at equilibrium and at time $(\mathrm{t})$, respectively. A plot $\mathrm{t} / \mathrm{q}_{\mathrm{t}}$ versus $\mathrm{t}$ shows a straight line of slope $\left(1 / \mathrm{q}_{\mathrm{e}}\right)$ and an intercept of $\left(1 / \mathrm{K}_{2} \mathrm{q}_{\mathrm{e}}{ }^{2}\right)$.

\section{Results and Discussion}

\section{Characterization of the Synthesized Nanochitosan}

Figure 1a displayed FTIR of chitosan and nanochitosan, it showed a distinct shift of $\mathrm{OH}$ and $\mathrm{NH}$ to a lower wave number from $3437 \mathrm{~cm}^{-1}$ for chitosan to $3415 \mathrm{~cm}^{-1}$ for nanochitosan with large broadening indicating the physical interaction with TPP. Peaks of $\mathrm{C}=\mathrm{O}$ of amide (chitin part) at $1640 \mathrm{~cm}^{-1}$ and $\mathrm{C}-\mathrm{O}$ at $1150 \mathrm{~cm}^{-1}$ were obtained [53]. For nanochitosan a distinct peaks were appeared at 1080 and $1210 \mathrm{~cm}^{-1}$ for $\mathrm{P}-\mathrm{O}$ and $\mathrm{P}=\mathrm{O}$ streating, respectively.
Figure $1 \mathrm{~b}$ showed TEM images of the nanochitosan particle. The NCh had a relatively spherical shape and a narrow particle size distribution, with sizes ranging from 60 to $80 \mathrm{~nm}$. The $\mathrm{NCh}$ exists showed some aggregates due to the highly interactive attraction force between particles [54]. Figure $1 \mathrm{c}$ indicated the particle size of chitosan measured using zeta Sizer (Malvern instrument Version 7.04). The figure indicated that the average particle size of the nanoparticle was $98 \mathrm{~nm}$ with narrow distribution. The relatively higher particles size of chitosan in DLS rather in TEM is that the measurement in DLS was performed in aqueous media and the chitosan nanoparticles were in swollen state that give relatively larger size. However in TEM measurement the particles were in dried state and selected image were obtain to confirm the particle size.

\section{Characterization of the Composite Films}

\section{FTIR Spectra}

FT-IR spectra of the prepared AF film, and nanocomposites films have been investigated as shown in Fig. 2.

As shown in the Fig. 2, AF film have many peaks; the absorption peaks at $2928 \mathrm{~cm}^{-1}$ and 2885 were related to stretching $\mathrm{C}-\mathrm{H}$ bonds in $\mathrm{CH}_{3}$ and $\mathrm{CH}_{2}$. Another peak is at $2245 \mathrm{~cm}^{-1}$ which is assigned to presence of nitrile $(\mathrm{C} \equiv \mathrm{N})$ groups. Peak at $3436 \mathrm{~cm}^{-1}$ is may be related to $-\mathrm{OH}$ of adsorbed water by additives present in commercial AF [46]. The peaks at $1638 \mathrm{~cm}^{-1}$ and $1738 \mathrm{~cm}^{-1}$ results from presence of $\mathrm{C}=\mathrm{O}$ related to comonomers like butyl acrylate and methyl acrylate and peaks at 1073 and $1237 \mathrm{~cm}^{-1}$ may be related to and $\mathrm{C}-\mathrm{O}$ stretching, the peaks at $1371 \mathrm{~cm}^{-1}$ is related to bending motions of $\mathrm{C}-\mathrm{H}$ bond [55].

FTIR of composites films AF-NCh and AF-NCh$\mathrm{EPH}$ declares that the intensity of $\mathrm{C} \equiv \mathrm{N}$ and $\mathrm{C}=\mathrm{O}$ ester is decreased compared to pure $\mathrm{AF}$ and observed at $2246 \mathrm{~cm}^{-1}$, $1738 \mathrm{~cm}^{-1}$ and $1735 \mathrm{~cm}^{-1}$ respectively. $\mathrm{NH}$ and $-\mathrm{OH}$ peaks are observed at $3429 \mathrm{~cm}^{-1}$ and $3437 \mathrm{~cm}^{-1}$, respectively.

\section{SEM of AF and Nanocomposites Films}

Figure 3a showed the topography of plain surface of AF film, which revealed the highly porous structure. Figure $4 \mathrm{a}$ displayed the cross section of AF which declared the pores and macro voids structure resulted from spontaneous demixing of solvent (DMF) and non-solvent (water) during phase inversion process. Figures $3 \mathrm{~b}$ and $4 \mathrm{~b}$ showed the plain and cross section of composite AF-NCh, which declared the enlarged macrovoids with more pores structure. The figures also showed the inclusion of spherical shaped nanoparticles indicating nano-chitosan incorporation into $\mathrm{AF}$ matrix, which resulted in increasing the active sites for dye adsorption process. For the other prepared AF-NCh-EPH 
Fig. 1 a FTIR spectra of chitosan and nanochitosan, $\mathbf{b}$ TEM of nanochitosan and $\mathbf{c}$ DLS measurement of the nanochitosan (Color figure online)

Fig. 2 FTIR of collected spectra of AF, AF-NCh and AF-NCh$\mathrm{EPH}$
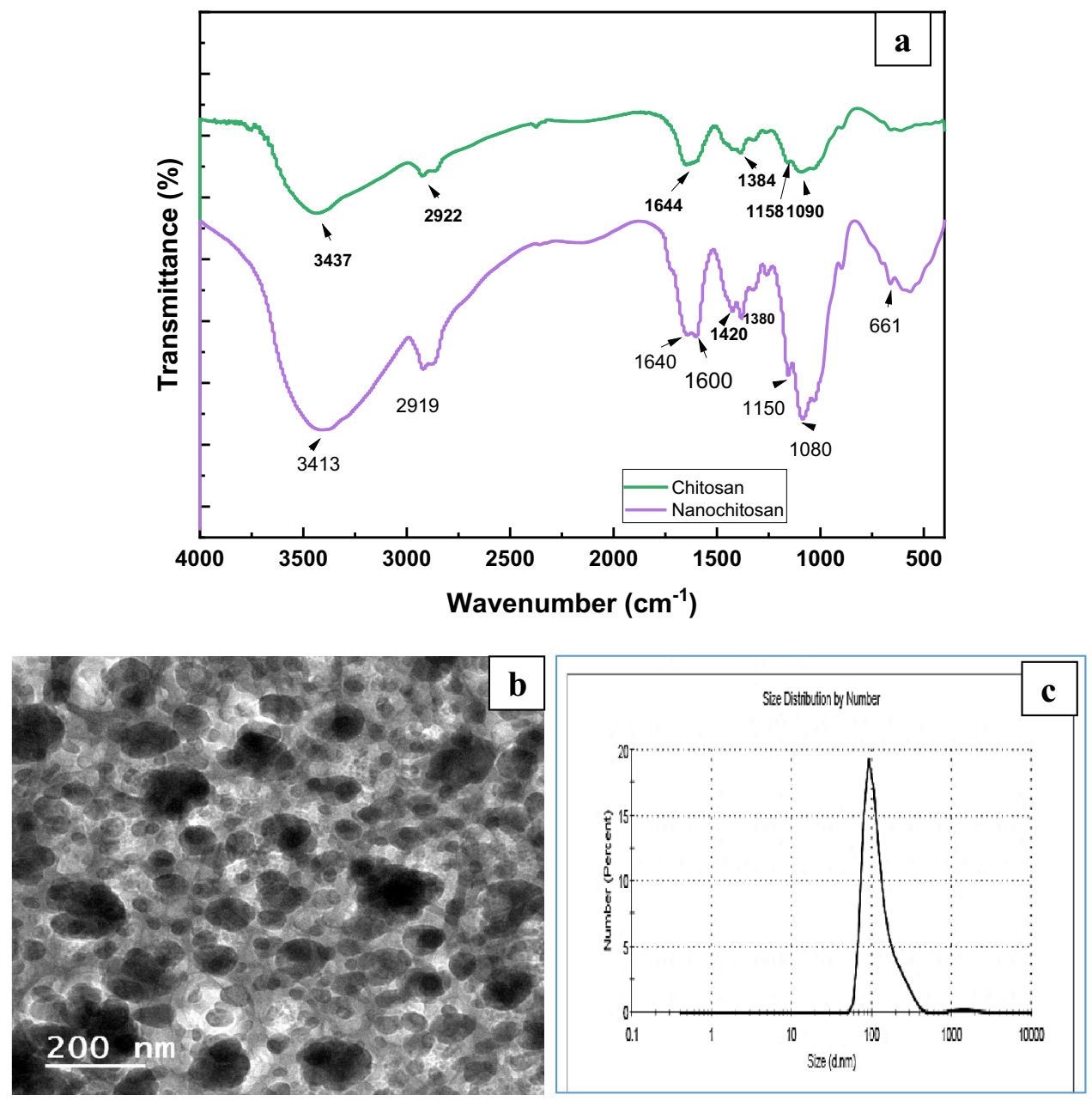

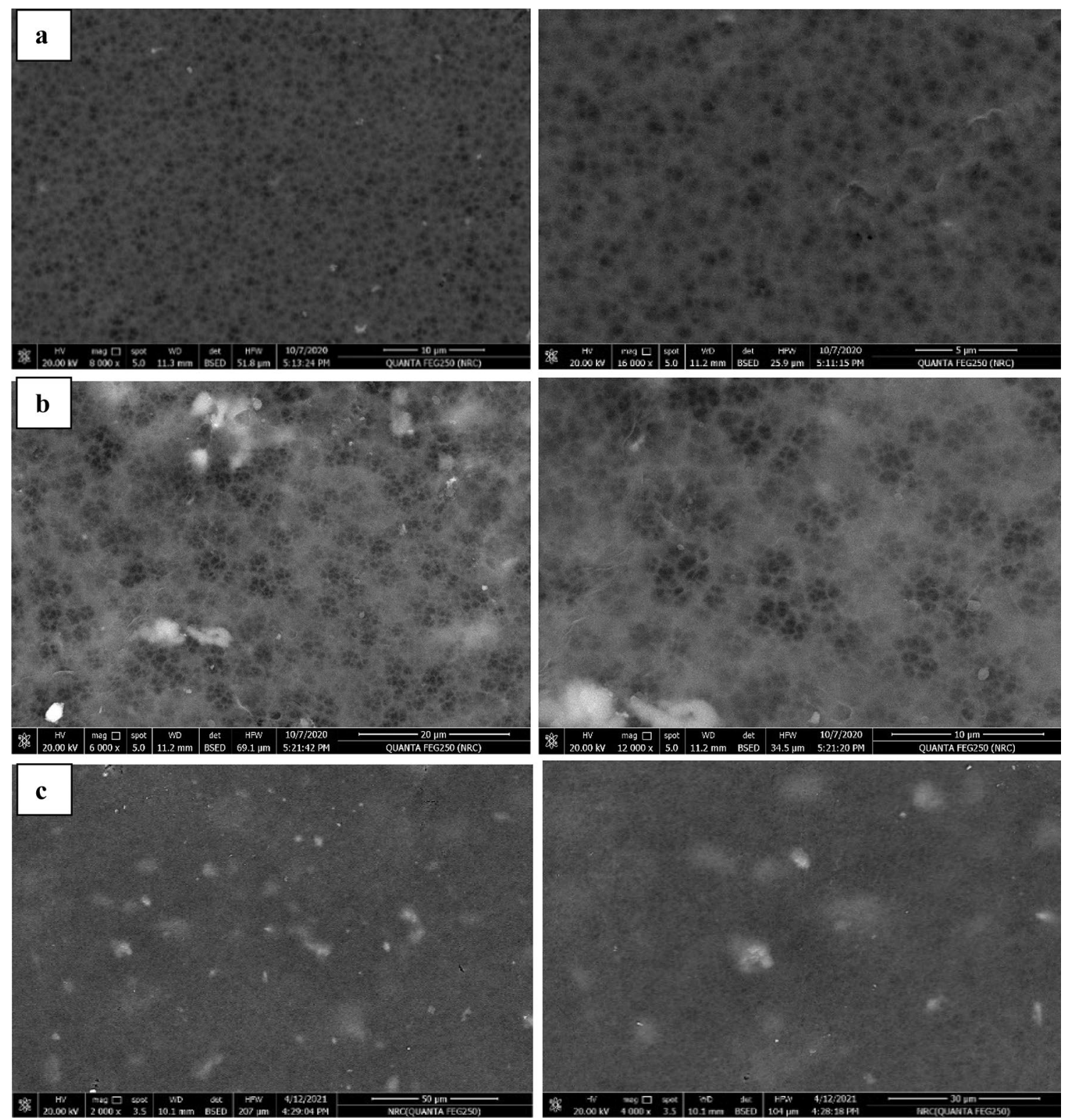

Fig. 3 SEM of film surface for a AF, b AF-NCh and $\mathbf{c}$ AF-NCh-EPH

nanocomposites; Figs. $3 \mathrm{c}$ and $4 \mathrm{c}$ displayed the surface and cross-section of the film, which revealed a significant fixation of NCh into AF matrix which leads to an enhancement in adsorption efficiency with good stability.

\section{Brunauer-Emmett-Teller (BET) Measurement}

BET analysis of the synthesized films is illustrated in Fig. 5 and summarized in Table 1. From BET data we can noticed that surface area of AF film decreased upon addition of $\mathrm{NCh}$ and NCh-EPH. This may be due to the inclusion of high content of nano-chitosan with high entangled force of these particles. But in spite of decrease the surface area of nanocomposite film but they have high adsorption capacity to CR dye compared to AF film because they have hydrophilic reactive function groups as $\left(-\mathrm{OH}\right.$ and $\left.-\mathrm{NH}_{2}\right)$ [56]. For AF-NCh-EPH has a larger surface area compared to AF$\mathrm{NCh}$, thus has a higher adsorption efficiency to $\mathrm{CR}$ removal. Also from nitrogen adsorption desorption isotherm and average pore size diameter of the synthesized films, they reveal the mesoporous structure of adsorbents films [57].

\section{Thermal Gravimetric Analysis}

The thermal stability of modified and unmodified AF-NCh was studied using thermal gravimetric analysis. Figure 6 

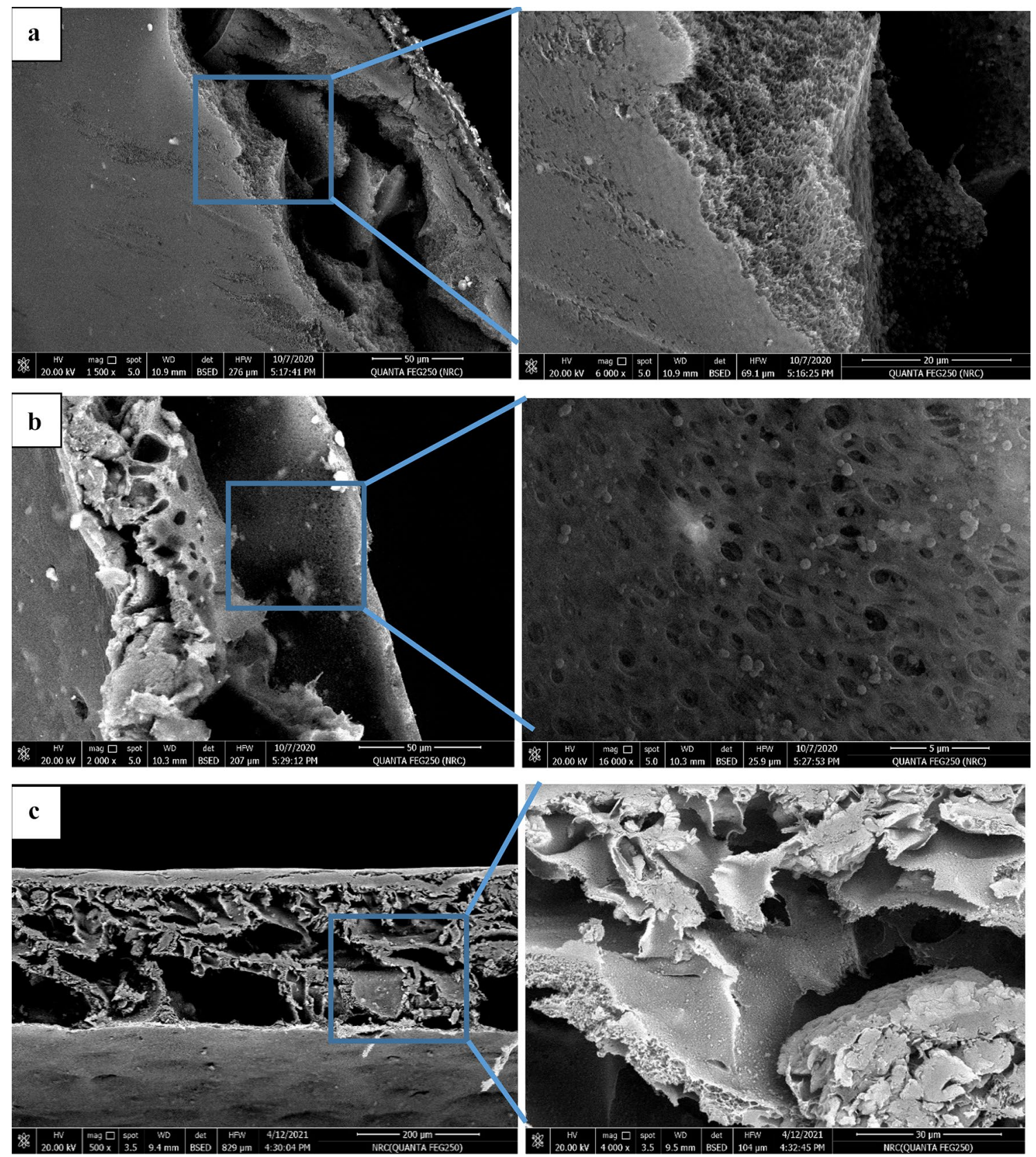

Fig. 4 SEM of film cross-section for a AF, b AF-NCh, c AF-NCh-EPH

illustrated TG and DTG curves of AF films; AF, AF-NCh and AF-NCh-EPH composites. For blank AF film there was a distinct one phase due to degradation process of the main chains. The onset degradation temperature was at $349{ }^{\circ} \mathrm{C}$. For the prepared nanocomposites AF-NCh and AF-NCh$\mathrm{EPH}$, it was obvious a distinct two phases of degradation process, which confirmed the successful physical mixing of nanochitosan into AF film matrix. For AF-NCh the first onset degradation process was at $289^{\circ} \mathrm{C}$, attributed to nanochitosan degradation. The second onset degradation temperature was at $353{ }^{\circ} \mathrm{C}$, for AF degradation. For AF-NCh-EPH the first onset degradation process was at $276{ }^{\circ} \mathrm{C}$, attributed to nanochitosan degradation. The second onset degradation temperature was at $343{ }^{\circ} \mathrm{C}$ for $\mathrm{AF}$ chains. It was noticed that the use of crosslinking EPH decrease the thermal stability of the nanocomposites, which may be due to the decrease in oriented packing chain of $\mathrm{AF}$ resulted from nanochitosan [58]. 


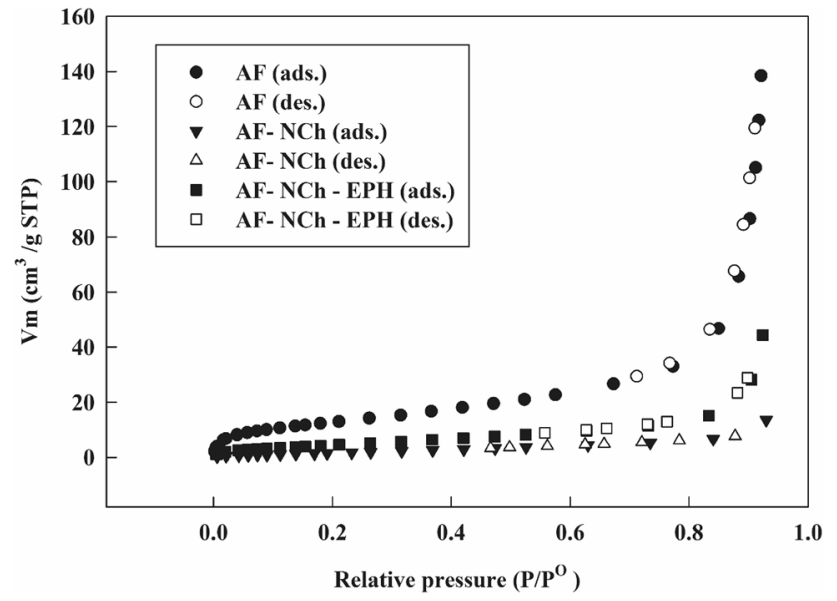

Fig. 5 BET adsorption-desorption isotherm of synthesized films

Table 1 BET surface area and the pore structure of the synthesized adsorbents

\begin{tabular}{llll}
\hline Sample & $\mathrm{S}_{\mathrm{BET}}\left(\mathrm{m}^{2} / \mathrm{g}\right)$ & $\begin{array}{l}\text { Pore volume } \\
\left(\mathrm{V}_{\mathrm{m}}\right)\left(\mathrm{cm}^{3} / \mathrm{g}\right)\end{array}$ & $\begin{array}{l}\text { Average } \\
\text { pore size } \\
(\mathrm{nm})\end{array}$ \\
\hline AF & 48 & 11.2 & 17.4 \\
AF-NCh & 9.3 & 2.1 & 9 \\
AF-NCh-EPH & 19 & 4.3 & 14.4 \\
\hline
\end{tabular}

\section{Adsorption Study}

\section{Effect of Loading Percent of NCh on Adsorption Behavior for Congo Red Dye}

The effect of loading percent of nano-chitosan into AF films was studied to measure the efficiency for CR dye removal. Weight of $0.025 \mathrm{~g}$ of AF-NCh with different nano-chitosan ratio $(0,10,20,30,40,50,60 \mathrm{wt} \%)$ was inserted into a $10 \mathrm{ml}$ of $200 \mathrm{mg} / \mathrm{l} \mathrm{CR}$ dye. The adsorption process occurred using a mechanical shaker at $50 \mathrm{rpm}$ for $24 \mathrm{~h}$. Figure 7 showed the relation between loaded nanochitosan percent and adsorption removal $\%(\% \mathrm{R})$ of CR dye. It was clear from the figure the increment of efficiency of CR dye upon increase of nanochitosan loaded percent onto AF film till $50 \mathrm{wt} \%$ after that it reached a plateau with no observed enhancement. The higher efficiency was due to high aspect ratio of reactive functional group (amine and hydroxyl groups) present in nanochitosan. Also the high surface area of nanoparticles may enhance the adsorption capacity [59-61]. One can see from the figure that the optimum removal efficiency (R\%) was about $98 \%$ of CR for nanochitosan with $50 \%$ loading into AF film, afterword they have no significant change of $\%$ R. This can be attributed the aggregation and accumulation of the nanoparticle during the composite preparation that decrease the active surface area for the adsorption [62].

\section{Effect of Dye Concentration}

Figure $8 \mathrm{a}$ and $\mathrm{b}$ declared the effect of $\mathrm{CR}$ concertation on adsorption capacity within a day $(24 \mathrm{~h})$ with a series of CR dye ranged from 100 to $800 \mathrm{mg} / \mathrm{l}$. From the figure, the best adsorption $\mathrm{R} \%$ was achieved at a $\mathrm{CR}$ dye concentration of $400 \mathrm{mg} / \mathrm{l}$ with values $92.5 \%$ and $96.8 \%$ for $\mathrm{AF}-\mathrm{NCh}$ and $\mathrm{AF}-$ NCh-EPH respectively. Also we can noticed that the higher concentration above $400 \mathrm{mg} / \mathrm{l}$ showed less percent removal efficiency because of the most active cites of the adsorbent was occupied and exhausted by CR dye molecules. The adsorption capacity was increased by increasing the dye concentration till $400 \mathrm{mg} / \mathrm{l}$ afterword there is no noticed increase in adsorption capacity indicating the saturation of active sites of adsorbent.

\section{Effect of $\mathrm{pH}$}

Table 2 summarize adsorption capacity for CR dye removal at different $\mathrm{pH}$. It can be seen from the table that the highest adsorption capacity was achieved at $\mathrm{pH} 5.5$, this due to; at relatively acidic condition $\mathrm{pH} 5.5$ the amino group of nanochitosan get protonated (cationic structure), which led to an increase in the interaction to the anionic dye (CR). While at a relatively neutral condition $\mathrm{pH} 6.8$ the cationic structure of nanochitosan loaded acrylic fiber waste decreased and the adsorption capacity of $\mathrm{CR}$ is decreased. At $\mathrm{pH} 8$ adsorption capacity appears to significantly decrease for the CR dye. This due to, at slightly basic solution the negative charge of $\mathrm{OH}^{-}$groups made a repulsive force of CR dye anionic structure, thus desorption process predominates [22]. On the other hand the $\mathrm{CR}$ dye aromatic moiety structure is sensitive to lower below $\mathrm{pH}$ below 5, the color is changed to deep blue and the dye get precipitated due to the hydrophobic interaction between the dye molecules [63].

\section{Effect of Contact Time}

Figure 9a indicated the effect of contact time on the adsorption capacity of composite films for CR dye. As it can be seen from the figure that the increase the time the increased adsorption capacity for both films (AF/NCh and AF/NCH$\mathrm{EPH})$. The increased capacity was due to the available reactive functional groups that consumed over the progress of time. The figure showed slow adsorption pattern; as it need much time for attain equilibrium, and this result may be due to the relative hydrophobic nature of the polymer matric that render the movement of the dye molecules into the bulk of polymer matrix. 
Fig. 6 a TG and b DTG curves of AF, AF-NCh and AF-NCh$\mathrm{EPH}$
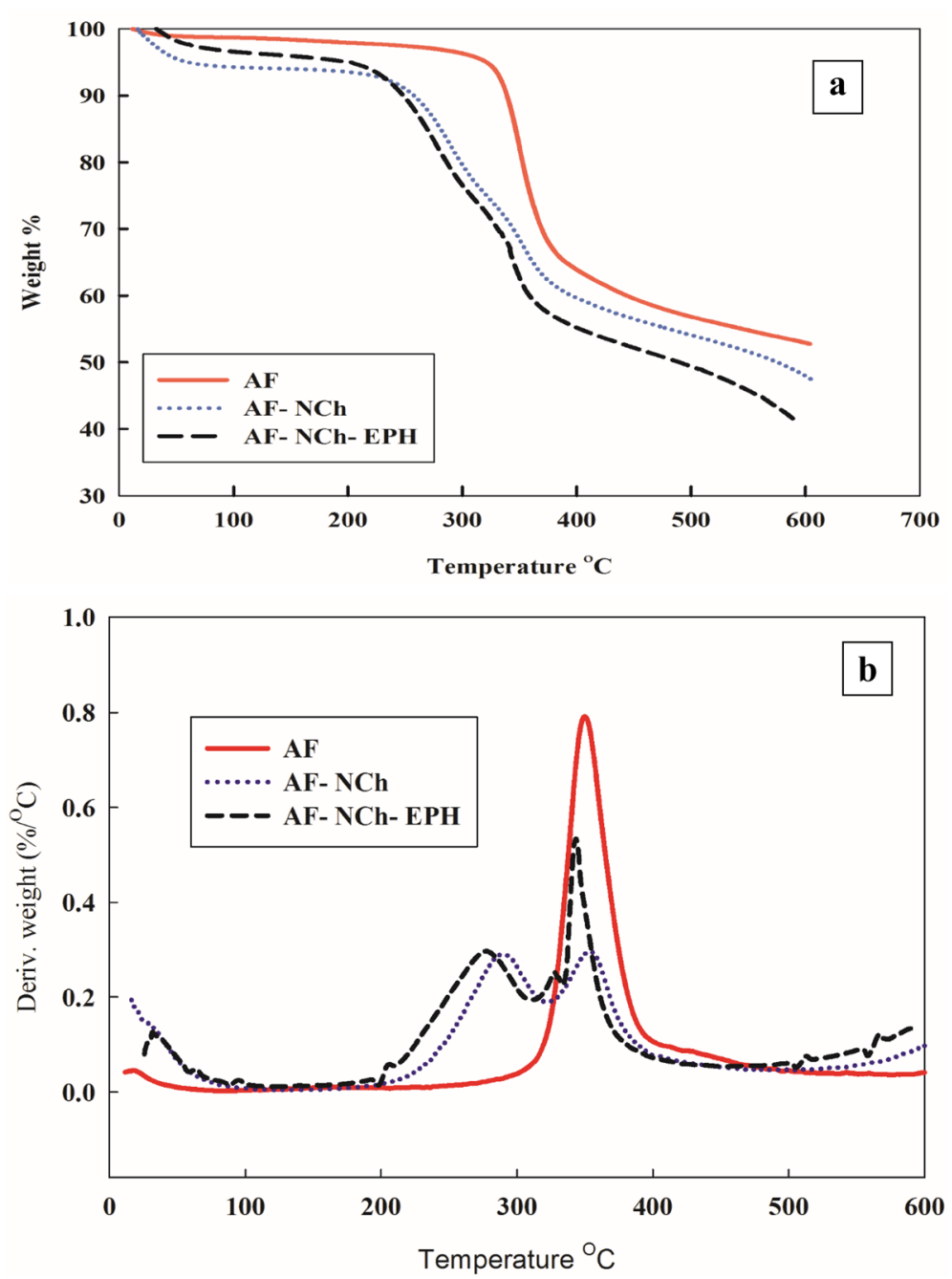

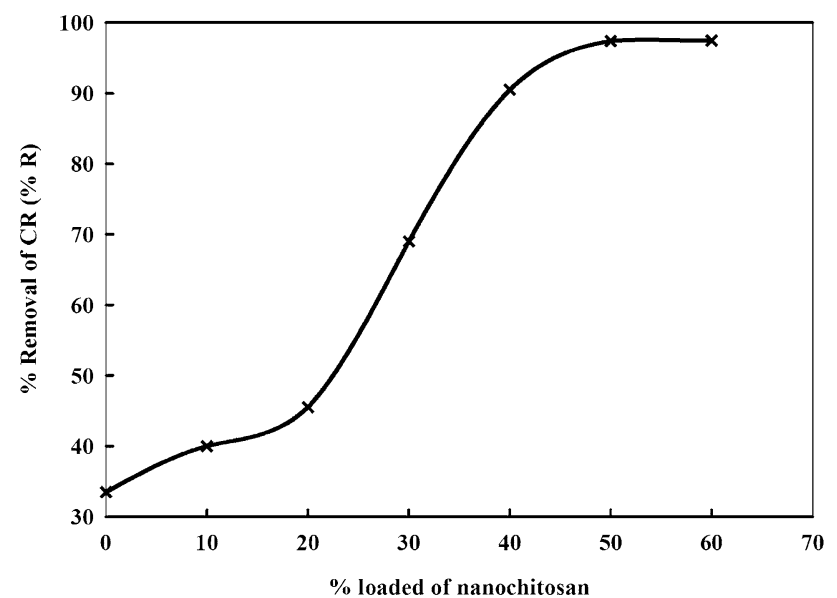

Fig. 7 Effect of nanochitosan percent loaded onto AF on \% removal of CR

\section{Effect of Adsorbent Dose}

In our study, different adsorbent dose, 1.25, 2.5, 5 and $7.5 \mathrm{~g} / 1$ of AF-NCh and AF-NCh-EPH films were used for removal of $400 \mathrm{ppm}$ CR dye solution for $240 \mathrm{~min}$. The $\% \mathrm{R}$ was plotted against dose of adsorbent as shown in Fig. 9b. From the figure the dye percent removal was enhanced and increased upon increase the adsorbent dose till the dose of $5 \mathrm{~g} / \mathrm{l}$ which consider the optimum dose. This was attributed to increase of surface area and active sites of adsorbent.

\section{Adsorption Isotherm Study}

The linear adsorption isotherms, Langmuir Freundlich and Temkin, were used to evaluate the adsorption adsorbate affinity interaction. The Langmuir model was illustrated by a linear plot between a specific sorption (Ce/Qe) and the equilibrium concentration $(\mathrm{Ce})$. We get $1 / q_{\max }=$ slope and $1 / q_{\text {max }} k_{l}=$ intercept. For Freundlich isotherm was obtained by plotting linearized curve between $\log q_{e} \mathrm{mg} / \mathrm{g}$ and $\log C_{e}$ $\mathrm{mg} / \mathrm{l}$. We get $\log \mathrm{K}=$ intercept and $1 / \mathrm{n}=$ slope. For Temkin isotherm the curve was obtained by plotting qe with $\ln (\mathrm{Ce})$. The Linear Langmuir, Freundlich and Temkin isotherms 
Fig. 8 Effect of CR dye concentration on adsorption capacity and $\%$ dye removal of a AF$\mathrm{NCh}$ and $\mathbf{b}$ AF-NCh-EPH
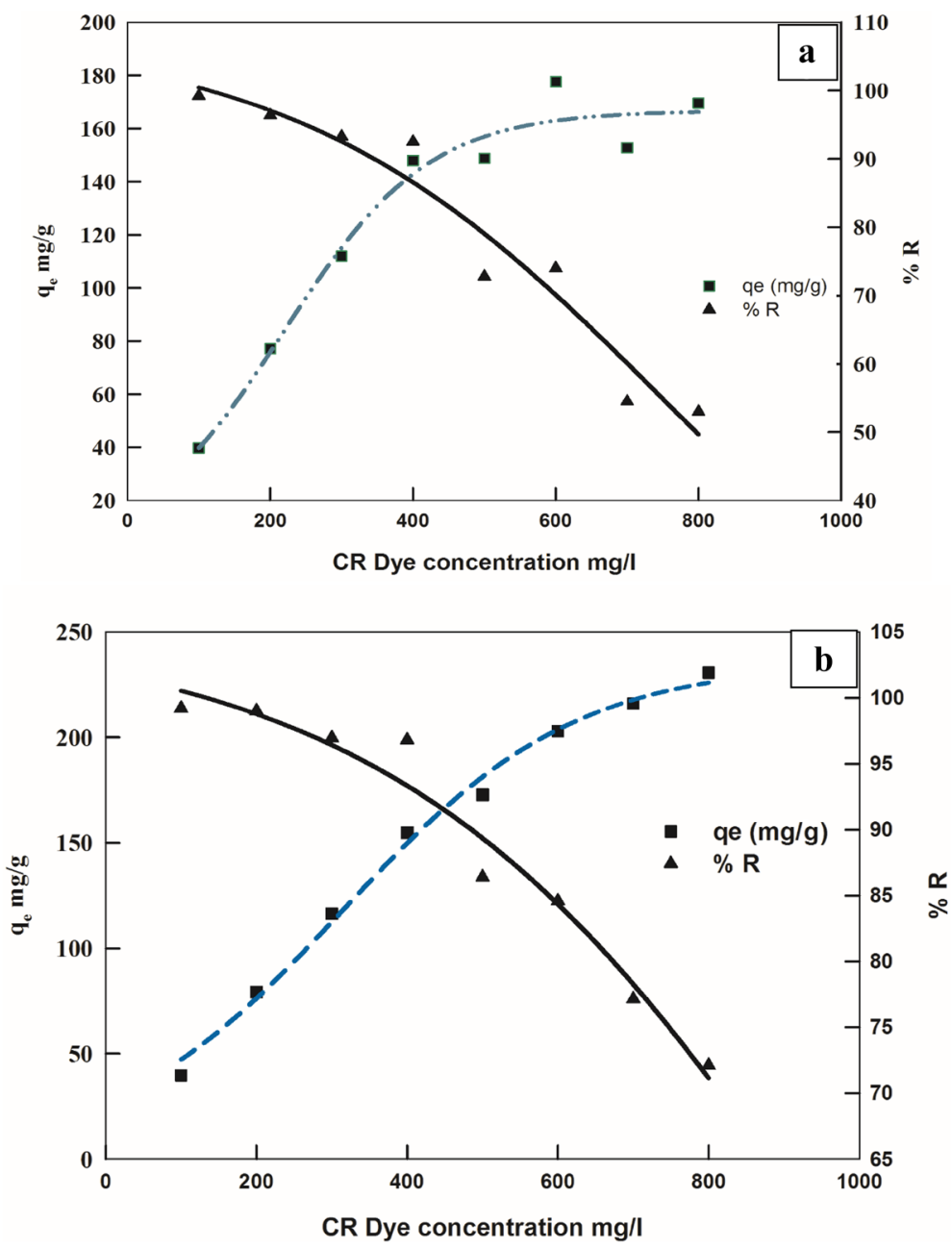

plots and their calculated parameters were showed in Fig. 10 and Table 3. From figure and calculated data, the adsorption nature of $\mathrm{CR}$ by $\mathrm{AF}-\mathrm{NCh}$ and $\mathrm{AF}-\mathrm{NCh}-\mathrm{EPH}$ were more fitted to Langmuir isotherm. This can be attributed to the high $\mathrm{R}^{2}$ value compared to Freundlich and Temkin isotherms (Table 3 ) and the relatively close value of qmax to the experimental one showed in Table 3. According to Langmuir isotherm the obtained adsorbent composite may have homogenous surface nature, and CR dye adsorbed completely to the synthesized films active sites via monolayer formation mechanism $[64,65]$. Also equilibrium factor $\left(\mathrm{R}_{1}\right)$

Table 2 Effect of $\mathrm{pH}$ variation on adsorption capacity of synthesized films

\begin{tabular}{llll}
\hline Dye conc. mg/l & $\mathrm{pH}$ & $\begin{array}{l}\mathrm{q} \text { mg/g (AF- } \\
\text { NCh) }\end{array}$ & $\begin{array}{l}\text { q mg/g } \\
\text { (AF-NCh- } \\
\text { EPH) }\end{array}$ \\
\hline 400 & 5.5 & 148 & 154.8 \\
& 6.8 & 128 & 136 \\
& 8 & 114.4 & 138.8 \\
\hline
\end{tabular}

derived from Langmuir isotherm ranged from 0.052 to 0.0068 and 0.086 to 0.011 for AF-NCh and AF-NCh-EPH, respectively, which indicates favored $\mathrm{CR}$ dye to the nanocomposites adsorbent materials [66].

\section{Kinetic Study}

Pseudo first and second order models were adopted for our adsorption study of CR dye on AF-NCh and AF-NCh-EPH composite films. The linearized curves for the two models were represented in Fig. 11. The calculated parameters were summarized in Table 4. From these data, we can conclude that pseudo second order mechanism is most fitted for adsorption of CR dye on the two synthesized composite films. The value of $\mathrm{R}^{2}$ of pseudo second order is higher than of pseudo first order as shown in Table 4. Also the calculated values of qe were 125 and 128.2 for AF-NCh and AF-NChEPH, respectively. 
Fig. 9 Effect of a adsorbent time and $\mathbf{b}$ adsorption dose on CR dye $\% \mathrm{R}$

\section{Effect of Film Regeneration}

Regeneration of the adsorbent is an important step from economic point of view and practical use of an adsorbent in industries. The prepared nanocomposite films (AF-NCh and $\mathrm{AF}-\mathrm{NCh}-\mathrm{EPH})$ were regenerated using (50:50) ethanol: water solution. Five cycles experiment were employed using $400 \mathrm{mg} / \mathrm{l} \mathrm{CR}$ dye solution. The results were shown in Fig. 12. From the illustrated data we can state that; after five cycles of using the synthesized film the adsorption capacity decreased by approximately $30 \%$ of their initial values. Thus the synthesized AF-NCh and AF-NCh-EPH films can be used several times as an adsorbent for CR dye with relatively good stability.

\section{Comparative Study}

We have also compared the maximum sorption capacity $\left(\mathrm{q}_{\max }\right)$ for the adsorption of CR dye onto the prepared nanocomposites with other nano-adsorbents and are presented in Table 5. It is observed from the table that the CR dye adsorption capacity of blended AF/nanochitosan films is higher than the previous reported nano-adsorbents based on acrylonitrile polymer or nanochitosan. Thus the prepared
AF-NCh and AF-NCH-EPH have great potential for CR from aqueous media.

\section{Conclusion}

This work was a trial for utilize waste to treat waste whereas recycling of acrylic fibers (AF) waste into adsorbent films incorporated with ecofriendly nanochitosan $(\mathrm{NCh})$ with high ratio were employed. Preparation of nanocomposites films, AF-NCh and AF-NCh-EPH were performed. The nanocomposite films were well characterized via instrumental techniques and evaluated for their removal capability for anionic dye (Congo red) from aqueous solution. The results indicated the efficiency of the prepared films for removing of CR with maximum adsorption capacities of 169 and $230 \mathrm{mg} / \mathrm{g}$ for AF-NCh and AF-NCh-EPH, respectively. The adsorption was most fitted to Langmuir isotherm and pseudo second order mechanism. The prepared adsorbents showed relative stability after 5 cycles of regeneration. Finally, the prospective research on acrylic fiber waste is to be tested on other pollutants and real waste water, in addition other preparation condition can be performed as addition of pore former, 

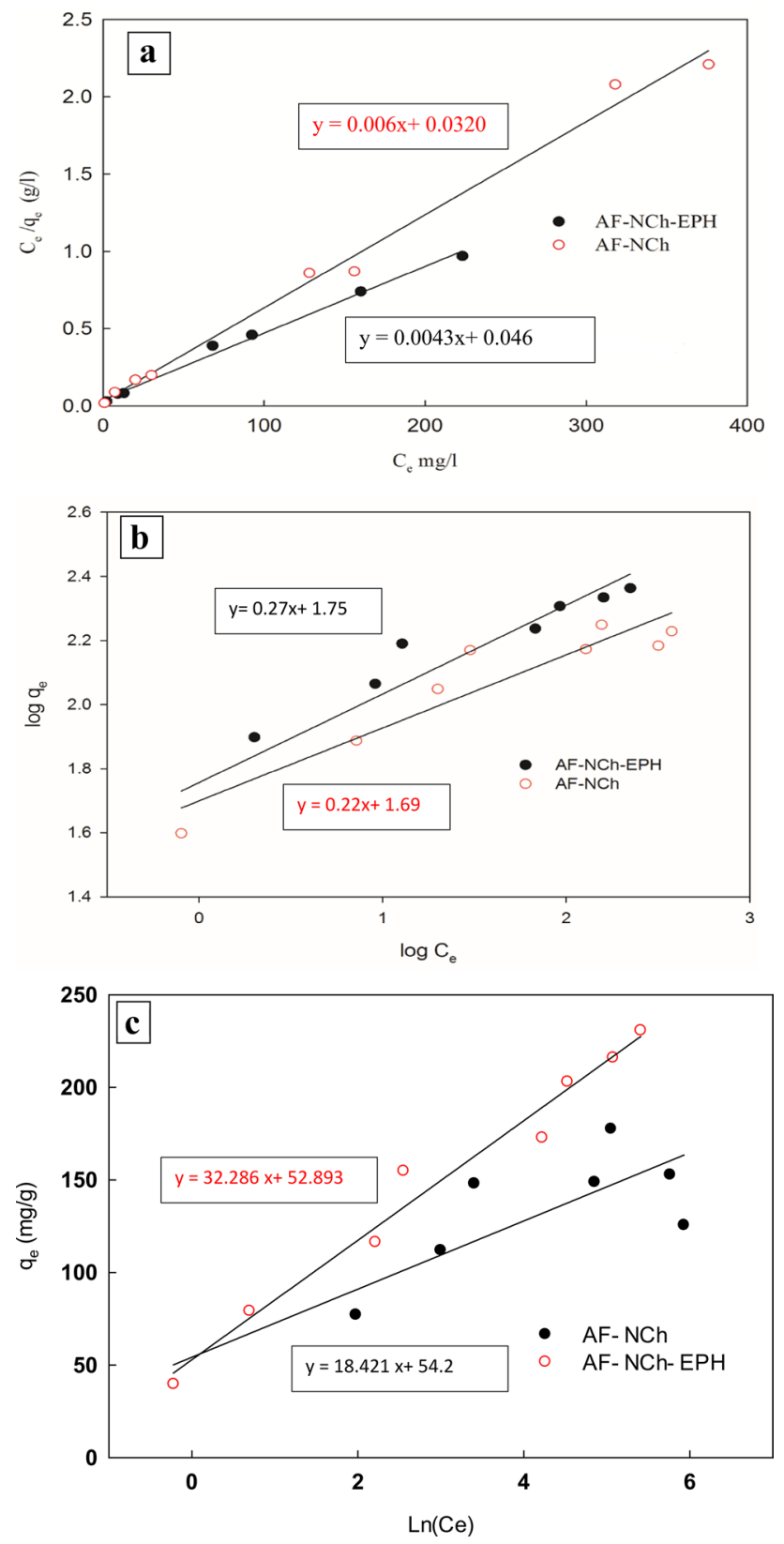

Fig. 10 Langmuir (a), Freundlich (b) and $\mathbf{c}$ Temkin isotherms for CR dye adsorption by AF-NCh and AF-NCh-EPH

choosing another solvent and reduce thickness of the film to enhance the porosity and surface area of the adsorbent.

Funding Open access funding provided by The Science, Technology \& Innovation Funding Authority (STDF) in cooperation with The Egyptian Knowledge Bank (EKB).
Table 3 Langmuir \& Freundlich isotherms parameters for CR dye adsorption by AF-NCh and AF-NCh-EPH adsorbents

\begin{tabular}{llll}
\hline Isotherm model & Parameter & AF-NCh & AF-NCh-EPH \\
\hline Langmuir & $\mathrm{R}^{2}$ & 0.992 & 0.997 \\
& $\mathrm{Kl}$ & 0.18 & 0.106 \\
& $\mathrm{q}_{\max }$ & 166.6 & 232.5 \\
\multirow{5}{*}{ Freundlich } & $\mathrm{q}_{\max (\text { experimental) }}$ & 169 & 230 \\
& $\mathrm{R}^{2}$ & 88 & 91 \\
& $\mathrm{~K}_{\mathrm{f}}$ & 48.9 & 56.2 \\
Temkin & $\mathrm{n}$ & 4.5 & 63.7 \\
& $\mathrm{R}^{2}$ & 0.74 & 0.97 \\
& $\mathrm{~B}$ & 18.4 & 32.2 \\
& $\mathrm{~A}$ & 18.5 & 4.8 \\
\hline
\end{tabular}

\section{Declarations}

Conflict of interest The authors confirm that there is no conflict of interest.

Open Access This article is licensed under a Creative Commons Attribution 4.0 International License, which permits use, sharing, adaptation, distribution and reproduction in any medium or format, as long as you give appropriate credit to the original author(s) and the source, provide a link to the Creative Commons licence, and indicate if changes were made. The images or other third party material in this article are included in the article's Creative Commons licence, unless indicated otherwise in a credit line to the material. If material is not included in the article's Creative Commons licence and your intended use is not permitted by statutory regulation or exceeds the permitted use, you will need to obtain permission directly from the copyright holder. To view a copy of this licence, visit http://creativecommons.org/licenses/by/4.0/.

\section{References}

1. Holkar CR, Jadhav AJ, Pinjari DV et al (2016) A critical review on textile wastewater treatments: possible approaches. J Environ Manage. https://doi.org/10.1016/j.jenvman.2016.07.090

2. Abdi J, Vossoughi M, Mahmoodi NM, Alemzadeh I (2017) Synthesis of metal-organic framework hybrid nanocomposites based on GO and CNT with high adsorption capacity for dye removal. Chem Eng J 326:1145-1158. https://doi.org/10.1016/j.cej.2017. 06.054

3. Rauf MA, Salman Ashraf S (2012) Survey of recent trends in biochemically assisted degradation of dyes. Chem Eng J 209:520530. https://doi.org/10.1016/j.cej.2012.08.015

4. Raval NP, Shah PU, Shah NK (2016) Adsorptive amputation of hazardous azo dye Congo red from wastewater: a critical review. Environ Sci Pollut Res 23:14810-14853. https://doi.org/10.1007/ s11356-016-6970-0

5. Shu J, Wang Z, Huang Y et al (2015) Adsorption removal of Congo red from aqueous solution by polyhedral $\mathrm{Cu} 2 \mathrm{O}$ nanoparticles: kinetics, isotherms, thermodynamics and mechanism analysis. J Alloys Compd 633:338-346. https://doi.org/10.1016/j.jallc om.2015.02.048 
Fig. 11 Pseudo first order (a) and second order (b) for CR dye adsorption by AF-NCh and AF-NCh-EPH
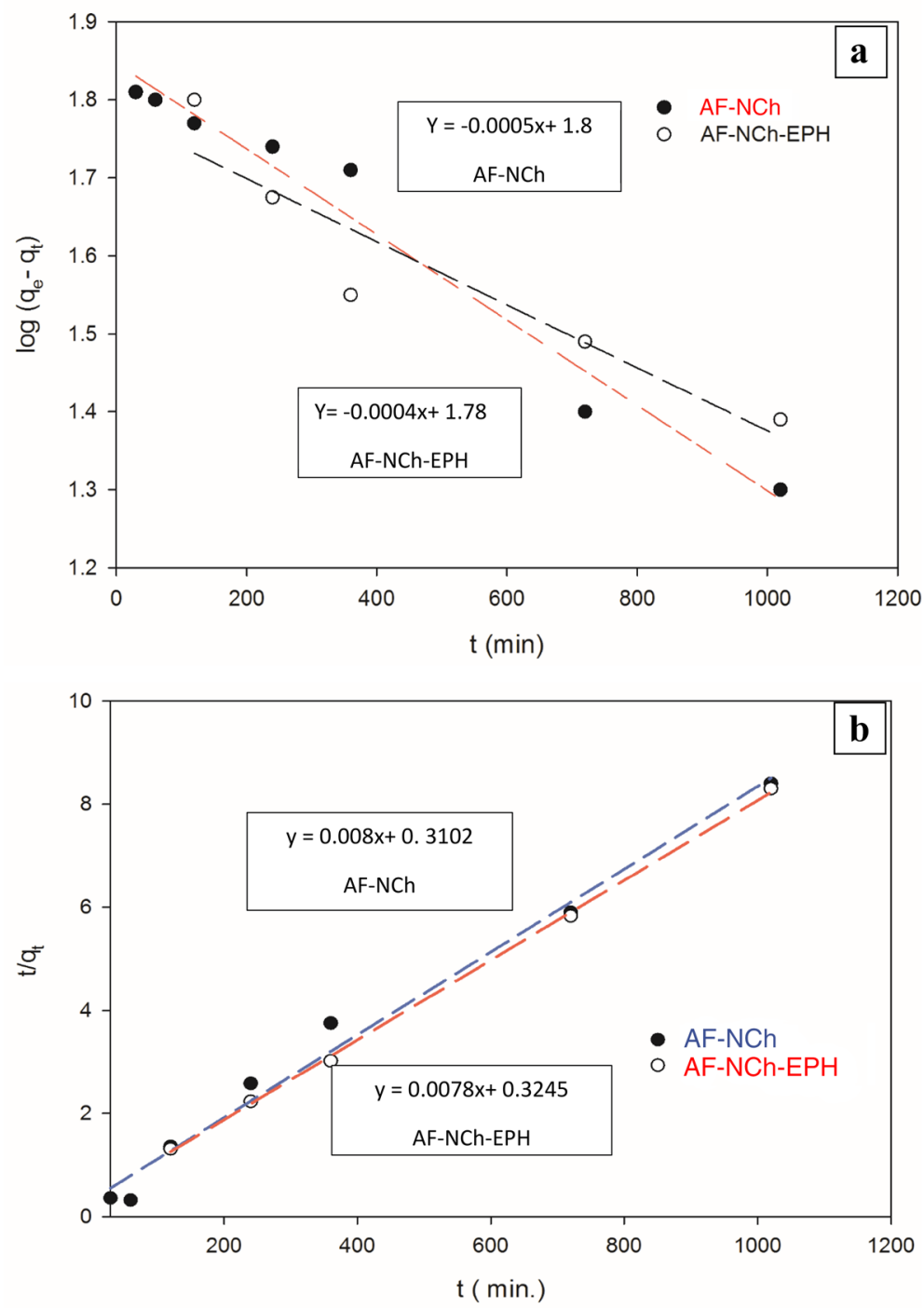

Table 4 Pseudo first order and pseudo second order parameters for $\mathrm{CR}$ dye adsorption by AF-NCh and AF-NCh-EPH

\begin{tabular}{llll}
\hline & Parameter & AF-NCh & AF-NCh-EPH \\
\hline 1st order & $\mathrm{R}^{2}$ & 0.97 & 0.88 \\
& $\mathrm{~K} 1$ & $1.15 \times 10^{-3}$ & $9.2 \times 10^{-4}$ \\
& $\mathrm{q}_{\mathrm{e}}$ & 70.8 & 60.25 \\
\multirow{5}{*}{ 2nd order } & $\mathrm{R}^{2}$ & 98 & 99 \\
& $\mathrm{~K} 2$ & $2.06 \times 10^{-4}$ & $1.87 \times 10^{-4}$ \\
& $\mathrm{q}_{\mathrm{e}}$ & 125 & 128.2 \\
\hline
\end{tabular}

6. Munagapati VS, Kim DS (2016) Adsorption of anionic azo dye Congo Red from aqueous solution by cationic modified orange peel powder. J Mol Liq 220:540-548. https://doi.org/10.1016/j. molliq.2016.04.119

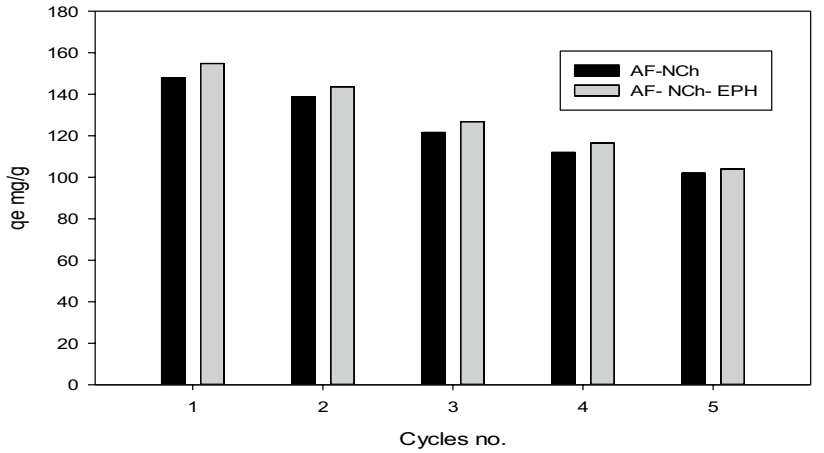

Fig. 12 Effect of cycles on adsorption capacity for CR dye by AFNCh and AF-NCh-EPH

7. Wang J, Qin L, Lin J et al (2017) Enzymatic construction of antibacterial ultrathin membranes for dyes removal. Chem Eng J 323:56-63. https://doi.org/10.1016/j.cej.2017.04.089 
Table 5 Comparison of adsorption capacities of various adsorbents for removal of CR dye

\begin{tabular}{lllll}
\hline Adsorbent & $\mathrm{q}_{\max } \mathrm{mg} / \mathrm{g}$ & $\begin{array}{l}\text { Adsorption iso- } \\
\text { therm model }\end{array}$ & $\begin{array}{l}\text { Adsorbate } \\
\text { (Dye) }\end{array}$ & References \\
\hline PAN-PEI 2D nano fibrous mat & 77.5 & Lang. & $\mathrm{CR}$ & {$[67]$} \\
Functionalized PAN-EDA nanofibers & 130 & Lang. & $\mathrm{CR}$ & {$[68]$} \\
PAN/Fe $\mathrm{O}_{3}$ nanocomposite fibers & 52 & Lang. & $\mathrm{CR}$ & {$[69]$} \\
Chitosan/montmorillonite nanocomposite & 54.2 & Lang. & $\mathrm{CR}$ & {$[70]$} \\
AF-NCh & 166.6 & Lang. & $\mathrm{CR}$ & Our study \\
AF- NCh-EPH & 232.5 & Lang. & $\mathrm{CR}$ & Our study \\
\hline
\end{tabular}

8. Peng Y, Zhang Y, Huang H, Zhong C (2018) Flexibility induced high-performance MOF-based adsorbent for nitroimidazole antibiotics capture. Chem Eng J 333:678-685. https://doi.org/10. 1016/j.cej.2017.09.138

9. Sarro M, Gule NP, Laurenti E et al (2018) ZnO-based materials and enzymes hybrid systems as highly efficient catalysts for recalcitrant pollutants abatement. Chem Eng J 334:2530-2538. https:// doi.org/10.1016/j.cej.2017.11.146

10. Tang L, Yu J, Pang Y et al (2018) Sustainable efficient adsorbent: alkali-acid modified magnetic biochar derived from sewage sludge for aqueous organic contaminant removal. Chem Eng $\mathrm{J}$ 336:160-169. https://doi.org/10.1016/j.cej.2017.11.048

11. Rani S, Mahajan RK (2012) Kinetic and equilibrium studies of adsorption of dye congo red from aqueous solutions on bagasse charcoal and banana peels. J Surf Sci Technol 28:133-147

12. Adegoke KA, Bello OS (2015) Dye sequestration using agricultural wastes as adsorbents. Water Resour Ind 12:8-24. https://doi. org/10.1016/j.wri.2015.09.002

13. Crini G (2006) Non-conventional low-cost adsorbents for dye removal: a review. Bioresour Technol 97:1061-1085. https://doi. org/10.1016/j.biortech.2005.05.001

14. Rafatullah M, Sulaiman O, Hashim R, Ahmad A (2010) Adsorption of methylene blue on low-cost adsorbents: a review. J Hazard Mater 177:70-80. https://doi.org/10.1016/j.jhazmat.2009.12.047

15. Salleh MAM, Mahmoud DK, Karim WAWA, Idris A (2011) Cationic and anionic dye adsorption by agricultural solid wastes: a comprehensive review. Desalination 280:1-13. https://doi.org/10. 1016/j.desal.2011.07.019

16. Srinivasan A, Viraraghavan T (2010) Decolorization of dye wastewaters by biosorbents: a review. J Environ Manage 91:1915-1929. https://doi.org/10.1016/j.jenvman.2010.05.003

17. Achour Y, Bahsis L, Ablouh E-H et al (2021) Insight into adsorption mechanism of Congo red dye onto Bombax Buonopozense bark Activated-carbon using central composite design and DFT studies. Surf Interfaces 23:100977

18. Rajappa A (2014) Kinetics of adsorption of Congo red onto multiwalled nano carbon. Int J Curr Res Chem Pharm Sci 1:18-23

19. Rajappa A, Ramesh K, Nandhakumar V (2014) Removal of Congo red dye from aqueous solution using $\mathrm{ZnCl} 2$ activated carbon prepared from Delonix regia pods (flame tree). Int J Chem Pharm Sci 2:961-971

20. Rajappa A, Ramesh K, Nandhakumar V, Ramesh H (2014) Kinetics of adsorption of Congo red dye onto commercial activated carbon from aqueous solution. J Environ Nanotechnol 3:43-49. https://doi.org/10.13074/jent.2014.03.142067

21. Rajappa A, Ramesh K, Nandhakumar V, Ramesh H (2015) Equilibrium and isotherm studies of congo red adsorption onto commercial activated carbon. Int J CurrResChemPharmaSci 2:51-58

22. Mohamed NA, Al-Harby NF, Almarshed MS (2020) Enhancement of adsorption of Congo red dye onto novel antimicrobial trimellitic anhydride isothiocyanate-cross-linked chitosan hydrogels. Polym Bull 77:6135-6160. https://doi.org/10.1007/ s00289-019-03058-6

23. Raval NP, Shah PU, Ladha DG et al (2016) Comparative study of chitin and chitosan beads for the adsorption of hazardous anionic azo dye Congo Red from wastewater. Desalin Water Treat 57:9247-9262. https://doi.org/10.1080/19443994.2015.1027959

24. Feng T, Zhang F, Wang J, Huang Z (2011) Notice of retraction: adsorption of congo red by cross-linked chitosan film. In: 2011 5th International Conference on Bioinformatics and Biomedical Engineering. IEEE, pp 1-4

25. Kim TY, Park SS, Cho SY (2012) Adsorption characteristics of reactive black 5 onto chitosan beads cross-linked with epichlorohydrin. J Ind Eng Chem 18:1458-1464. https://doi.org/10.1016/j. jiec.2012.02.006

26. Cheung WH, Szeto YS, McKay G (2009) Enhancing the adsorption capacities of acid dyes by chitosan nano particles. Bioresour Technol 100:1143-1148. https://doi.org/10.1016/j.biortech.2008. 07.071

27. Rezaei H, Razavi A, Shahbazi A (2017) Removal of Congo red from aqueous solutions using nano-chitosan. Environ Resour Res $5: 25-34$

28. Karimi F, Ayati A, Tanhaei B et al (2022) Removal of metal ions using a new magnetic chitosan nano-bio-adsorbent: a powerful approach in water treatment. Environ Res 203:111753. https:// doi.org/10.1016/j.envres.2021.111753

29. Yulizar Y, Utari T, Apriandanu DOB, Putri YRP (2019) Chitosan nanoparticles on a natural zeolite as an efficient adsorbent for Congo red. IOP Conf Ser Mater Sci Eng. https://doi.org/10.1088/ 1757-899X/496/1/012005

30. Rajendran S, Priya TAK, Khoo KS et al (2022) A critical review on various remediation approaches for heavy metal contaminants removal from contaminated soils. Chemosphere 287:132369. https://doi.org/10.1016/j.chemosphere.2021.132369

31. Abdelhamid AE, Labena A, Mansor ES et al (2021) Highly efficient adsorptive membrane for heavy metal removal based on Ulva fasciata biomass. Biomass Convers Biorefinery. https://doi.org/10. 1007/s13399-020-01250-7

32. Chatterjee S, Chatterjee T, Woo SH (2010) A new type of chitosan hydrogel sorbent generated by anionic surfactant gelation. Bioresour Technol 101:3853-3858. https://doi.org/10.1016/j.biortech. 2009.12.089

33. Jiang R, Yao J, Zhu H et al (2014) Effective decolorization of congo red in aqueous solution by adsorption and photocatalysis using novel magnetic alginate/ $\gamma$ - $\mathrm{Fe} 2 \mathrm{O} 3 / \mathrm{CdS}$ nanocomposite. Desalin Water Treat 52:238-247. https://doi.org/10.1080/19443 994.2013.787551

34. Hou H, Zhou R, Wu P, Wu L (2012) Removal of Congo red dye from aqueous solution with hydroxyapatite/chitosan composite. Chem Eng J 211-212:336-342. https://doi.org/10.1016/j.cej.2012. 09.100

35. Du Q, Sun J, Li Y et al (2014) Highly enhanced adsorption of Congo red onto graphene oxide/chitosan fibers by wet-chemical 
etching off silica nanoparticles. Chem Eng J 245:99-106. https:// doi.org/10.1016/j.cej.2014.02.006

36. Karaman C, Karaman O, Show P, Orooji Y (2021) Utilization of a double-cross-linked amino-functionalized three-dimensional graphene networks as a monolithic adsorbent for methyl orange removal: equilibrium, kinetics, thermodynamics and artificial neural network modeling. Environ Res. https://doi.org/10.1016/j. envres.2021.112156

37. Karimi-Maleh H, Khataee A, Karimi F et al (2021) A green and sensitive guanine-based DNA biosensor for idarubicin anticancer monitoring in biological samples: a simple and fast strategy for control of health quality in chemotherapy procedure confirmed by docking investigation. Chemosphere. https://doi.org/10.1016/j. chemosphere.2021.132928

38. Karimi-maleh H, Karimi F, Fu L et al (2022) Cyanazine herbicide monitoring as a hazardous substance by a DNA nanostructure biosensor. J Hazard Mater. https://doi.org/10.1016/j.jhazmat.2021. 127058

39. Al Sharabati M, Abokwiek R, Al-Othman A et al (2021) Biodegradable polymers and their nano-composites for the removal of endocrine-disrupting chemicals (EDCs) from wastewater: a review. Environ Res 202:111694. https://doi.org/10.1016/j.envres. 2021.111694

40. Abdelhamid AE, El-Sayed AA, Khalil AM (2020) Polysulfone nanofiltration membranes enriched with functionalized graphene oxide for dye removal from wastewater. J Polym Eng 40:833-841. https://doi.org/10.1515/polyeng-2020-0141

41. Yunessnia Lehi A, Akbari A (2017) Novel membrane adsorbents prepared by waste fibers of mechanized carpet for Persian Orange X removal. Environ Nanotechnol Monit Manage 8:209-218. https://doi.org/10.1016/j.enmm.2017.08.004

42. Chen M, Wang C, Fang W et al (2013) Electrospinning of calixarene-functionalized polyacrylonitrile nanofiber membranes and application as an adsorbent and catalyst support. Langmuir 29:11858-11867. https://doi.org/10.1021/la4017799

43. Jadoo SA, Naser JA (2020) Adsorption optimization of Congo red dye onto electrospun nanofibers of polyacrylonitrile functionalized with Fe3O4 nanoparticles. IOP Conf Ser Mater Sci Eng. https://doi.org/10.1088/1757-899X/928/5/052024

44. Jadoo SA, Naser JA (2019) Adsorption thermodynamic study of Congo red dye on electrospun nanofibers mat of polyacrylonitrile. J Glob Pharma Technol 11:401-411

45. Labena A, Abdelhamid AE, Husien S et al (2021) Grafting of acrylic membrane prepared from fibers waste for dyes removal: methylene blue and congo red. Separations 8:42. https://doi.org/ 10.3390/separations 8040042

46. Orabi AH, Abdelhamid AES, Salem HM, Ismaiel DA (2020) New adsorptive composite membrane from recycled acrylic fibers and Sargassum dentifolium marine algae for uranium and thorium removal from liquid waste solution. J Radioanal Nucl Chem 326:1233-1247. https://doi.org/10.1007/s10967-020-07403-2

47. Diab A, Gobouri AA, Azab E (2021) Removal of methylene blue and Congo red using adsorptive. Plants 10:384

48. Govindarajan C, Ramasubramaniam S, Gomathi T et al (2011) (2011) Sorption studies of $\mathrm{Cr}$ (VI) from aqueous solution using nanochitosan-carboxymethyl cellulose blend. Arch Appl Sci Res 3(4):127-138

49. Dehghani MH, Dehghan A, Najafpoor A (2017) Removing reactive red 120 and 196 using chitosan/zeolite composite from aqueous solutions: kinetics, isotherms, and process optimization. J Ind Eng Chem 51:185

50. El-Harby NF, Ibrahim SMA, Mohamed NA (2017) Adsorption of Congo red dye onto antimicrobial terephthaloyl thiourea crosslinked chitosan hydrogels. Water Sci Technol 76:2719-2732. https://doi.org/10.2166/wst.2017.442
51. Kołodyńska D, Hałas P, Franus M, Hubicki Z (2017) Zeolite properties improvement by chitosan modification-sorption studies. J Ind Eng Chem 52:187-196. https://doi.org/10.1016/j.jiec.2017. 03.043

52. El-Ghaffar MAA, Elawady MM, Rabie AM, Abdelhamid AE (2020) Enhancing the RO performance of cellulose acetate membrane using chitosan nanoparticles. J Polym Res 27:337. https:// doi.org/10.1007/s10965-020-02319-7

53. Vinodhini PA, Sangeetha K, Gomathi T et al (2017) FTIR, XRD and DSC studies of nanochitosan, cellulose acetate and polyethylene glycol blend ultrafiltration membranes. Int J Biol Macromol. https://doi.org/10.1016/j.ijbiomac.2017.03.122

54. Ghadi A, Mahjoub S, Tabandeh F, Talebnia F (2014) Synthesis and optimization of chitosan nanoparticles: potential applications in nanomedicine and biomedical engineering. Casp J Intern Med 5:156-161

55. Grieve MC (1995) Another look at the classification of acrylic fibres, using FTIR microscopy. Sci Justice 35:179-190

56. Salehi S, Hosseinifard M (2020) Optimized removal of phosphate and nitrate from aqueous media using zirconium functionalized nanochitosan-graphene oxide composite. Cellulose 27:88598883. https://doi.org/10.1007/s10570-020-03382-5

57. Pandey G, Singh S, Hitkari G (2018) Synthesis and characterization of polyvinyl pyrrolidone (PVP)-coated $\mathrm{Fe} 3 \mathrm{O} 4$ nanoparticles by chemical co-precipitation method and removal of Congo red dye by adsorption process. Int Nano Lett 8:111-121. https://doi. org/10.1007/s40089-018-0234-6

58. Campana Filho SP (2015) Thermal behavior of cross-linked carboxymethylchitosan membranes. Braz J Therm Anal 4:70. https:// doi.org/10.18362/bjta.v4.i4.233

59. Sharma V, Rekha P, Mohanty P (2016) Nanoporous hypercrosslinked polyaniline: an efficient adsorbent for the adsorptive removal of cationic and anionic dyes. J Mol Liq 222:1091-1100. https://doi.org/10.1016/j.molliq.2016.07.130

60. Piri F, Mollahosseini A, Khadir A, Milani Hosseini M (2019) Enhanced adsorption of dyes on microwave-assisted synthesized magnetic zeolite-hydroxyapatite nanocomposite. J Environ Chem Eng 7:103338. https://doi.org/10.1016/j.jece.2019.103338

61. Kubra KT, Salman MS, Hasan MN (2021) Enhanced toxic dye removal from wastewater using biodegradable polymeric natural adsorbent. J Mol Liq 328:115468

62. Jawad AH, Abdulhameed AS, Reghioua A, Yaseen ZM (2020) Zwitterion composite chitosan-epichlorohydrin/zeolite for adsorption of methylene blue and reactive red 120 dyes. Int J Biol Macromol 163:756-765. https://doi.org/10.1016/j.jibiomac.2020.07. 014

63. Pigorsch E, Elhaddaoui A, Turrell S (1994) Spectroscopic study of $\mathrm{pH}$ and solvent effects on the structure of Congo red and its binding mechanism to amyloid-like proteins. Spectrochim Acta A Mol Spectrosc 50:2145-2152. https://doi.org/10.1016/0584-8539(94) 00151-0

64. Saadat S, Karimi-Jashni A (2011) Optimization of Pb(II) adsorption onto modified walnut shells using factorial design and simplex methodologies. Chem Eng J 173:743-749. https://doi.org/10. 1016/j.cej.2011.08.042

65. Saad M, Tahir H, Ali D (2017) Green synthesis of Ag-Cr-AC nanocomposites by Azadirachta indica and its application for the simultaneous removal of binary mixture of dyes by ultrasonicated assisted adsorption process using response surface methodology. Ultrason Sonochem 38:197-213. https://doi.org/10.1016/j.ultso nch.2017.03.022

66. Chatterjee S, Chatterjee T, Lim SR, Woo SH (2011) Effect of the addition mode of carbon nanotubes for the production of chitosan hydrogel core-shell beads on adsorption of Congo red from aqueous solution. Bioresour Technol 102:4402-4409. https://doi.org/ 10.1016/j.biortech.2010.12.117 
67. Sadasivam RK, Mohiyuddin S, Packirisamy G (2017) Electrospun polyacrylonitrile (PAN) templated 2D nanofibrous mats: a platform toward practical applications for dye removal and bacterial disinfection. ACS Omega 2:6556-6569. https://doi.org/10.1021/ acsomega.7b01101

68. Patel S, Hota G (2018) Synthesis of novel surface functionalized electrospun PAN nanofibers matrix for efficient adsorption of anionic CR dye from water. J Environ Chem Eng 6:5301-5310. https://doi.org/10.1016/j.jece.2018.08.013

69. Patel S (2016) Iron oxide nanoparticle-immobilized PAN nanofibers: synthesis and adsorption studies. RSC Adv. https://doi.org/ 10.1039/C5RA20345G

\section{Authors and Affiliations}

\section{Salah E. Selim ${ }^{1}$ (D) - Gamal A. Meligi ${ }^{2} \cdot$ Ahmed E. Abdelhamid ${ }^{3} \cdot$ Mahmoud A. Mabrouk $^{1} \cdot$ Ahmed I. Hussain $^{3}$}

1 Egyptian Academy for Engineering and Advanced Technology Affiliated To Ministry of Military Production, Al Salam City, Egypt

2 Chemistry Department, Faculty of Science, Ain Sham University, Cairo, Egypt
70. Wang L, Wang A (2007) Adsorption characteristics of Congo Red onto the chitosan/montmorillonite nanocomposite. J Hazard Mater 147:979-985. https://doi.org/10.1016/j.jhazmat.2007.01.145

Publisher's Note Springer Nature remains neutral with regard to jurisdictional claims in published maps and institutional affiliations.
3 Polymers and Pigments Department, National Research Center, 33 El-Buhouth St., Dokki, Cairo 12622, Egypt 